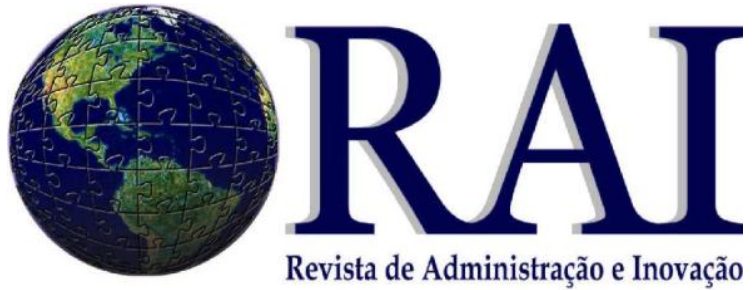

ARTICLES

\title{
HOW INTELLECTUAL PROPERTY RIGHTS ENCOURAGE PHARMACEUTICAL INNOVATION
}

\author{
Michael P. Ryan \\ George Washington University Law School \\ Director, Creative and Innovative Economy Center, George Washington University; PhD, \\ University of Michigan \\ E-mail: mryan@law.gwu.edu [USA]
}

\begin{abstract}
With patent laws governments intervene into the marketplace to provide incentives to innovators to invest their know-how, time, and money into the creation of inventions under circumstances of the appropriability problem associated with intangible assets. The intellectual property notion of trade secrecy means specific information that possesses commercial value and that reasonable efforts have been taken to keep it secret. Innovative pharmaceuticals, both radical and incremental, are especially susceptible to the appropriability problem in knowledge-based economic activity, for turning a prospective molecule as identified in the laboratory into a medicine that may be distributed in the public health system requires many years of computer modeling, animal-testing and, finally, clinical trial testing. Clinical trials are performed in three phases and each phase results in a plethora of data. Drug laws specify that such data are kept confidential by health regulatory authorities for a period of 5 years in the United States and for longer periods in most of Europe. Sufficiently strong appropriability regimes facilitate licensing and cross-licensing relationships between and among universities and business. Substantial empirical research supports the utility of the BayhDole model and doubts the existence of a patent anti-commons (editor note: the existence of numerous rights holders frustrates achieving a socially desirable outcome), in the life sciences.
\end{abstract}

Key words: Anti-commons, drug industry, innovative pharmaceuticals, patent.

RAI - Revista de Administração e Inovação

ISSN: $1809-2039$

Organização: Comitê Científico Interinstitucional

Editor Científico: Milton de Abreu Campanario

Avaliação: Double Blind Review pelo SEER/OJS

Revisão: gramatical, normativa e de formatação

RAI - Revista de Administração e Inovação, São Paulo, v. 5, n. 3, p. 110-125, 2008. 
ARTICLES - How intellectual property rights encourage phamaceutical

\section{INTRODUCTION}

Capitalist economies force business enterprises to innovate or die by establishing a competitive marketplace in which "the prime weapon of competition is not price but innovation" (BAUMOL, 2002, p. 4). It takes new ideas, methods, and inventions to increase productivity, improve industrial processes, and introduce better products in the marketplace. Innovative ideas, methods, and products depend upon knowledge and human capital, upon information-rich workers with know-how and learning capacity (ROSENBERG; LANDAU; MOWERY, 1992).

In our era, national comparative advantages are measured by how technology institutions manage and apply technology and practical knowledge (ZIEGLER, 1995). The notion of the national innovation system, i.e., "the cluster of institutions, policies, and practices that determine an industry or nation's capacity to generate and apply innovations" (STEIL; VICTOR; NELSON, 2002, p. 3), such as those in the United States and Europe, either encourages or discourages bio-medical R\&D. "There is no presumption that the system was, in some sense, consciously designed, or even that the set of institutions involved works together smoothly and coherently" (NELSON, 1993, p. 4). Institutional economists explain that a national innovation system composed of institutions, policies, and practices determines a country's innovative capacities. Most radical-innovation pharmaceuticals have been invented in either the United States or Europe and a preponderance of the incremental-innovation pharmaceuticals as well (SCRIABINE, 1999). The national innovation systems of the United States and Europe owe to long-established patterns of institutions and markets, including market and corporate structures, laws, policies, regulations, and public administration practices, and universities and technology institutions, and that these different national innovation systems yield strikingly different results with respect to technology innovation.

U.S. science and technology policy deliberately encourages public-private partnerships to develop new pharmaceuticals through intellectual property rights-based transfer of basic life sciences research findings into useful innovative medicines (BRANSCOMB, 1995; KUEHN; PORTER, 1981). Basic medical science research is conducted in universities and teaching-hospitals because of the many billions of dollars of public funding ( $\$ 27$ billion in support to medical science through the U.S. National Institutes of Health in 2006, but also euros invested into medical science research by Europeans and yen invested by Japanese) which aims to advance the state of medical science. The pharmaceutical companies play the commercializer role in a network of innovation that involves universities, research hospitals, and public research laboratories (GALAMBOS, 1995). The drug development researchers at the pharmaceutical companies learn from the medical scientists in the universities and research clinics and laboratories, then apply their own knowledge of chemistry, laboratory testing and evaluation, and human clinical trial testing evaluation and statistical analysis in order to develop a marketable drug. Medical scientists learn from the drug developers so that dynamic feed-back loops of knowledge exchange drive basic and applied medical knowledge advance.

Europeans, by contrast, have remained true to the original nineteenth-century model of the German research university (OWEN-SMITH et al., 2002; SOETE, 2007). European government laws constrain public-private research partnerships and European university cultural norms chill faculty-company market application-directed

RAI - Revista de Administração e Inovação, São Paulo, v. 5, n. 3, p. 110-125, 2008. 
collaborations. The U.S. Bayh-Dole law and its brethren in the early 1980 s provided for the patentability of publicly-funded research, thereby encouraging licensing to the private sector for further R\&D by existing and start-up firms. Other scholars, however, argue that Europeans should not apply the U.S. Bayh-Dole patent regime to their universities because their missions as research and education centers will be subverted (DAVID, 2007). Indeed, a number of legal scholars (EISENBERG, 1987, 1989, 1996; RAI, 1999, 2001) and institutional economists (MOWERY, 2007; MOWERY et al., 1999; MOWERY; SAMPAT; ZIEDONIS, 2002; NELSON, 2004) express the same concerns about the impact of the Bayh-Dole regime on the U.S. innovation system. These arguments and the related scholarship are reviewed.

\section{BIO-MEDICAL "TECHNOLOGY APPROPRIABILITY"}

Intellectual property rights create incentives to invest in and commercialize technologies and useful knowledge, explains institutional economist North (1981, p. 164): "A systematic set of incentives to encourage technological change and raise the private return on innovation closer to the social rate of return was established only with the patent system". With patent laws, governments intervene into the marketplace to provide incentives to innovators to invest their know-how, time, and money into the creation of inventions under circumstances of the appropriability problem associated with intangible assets (DAM, 1994, p. 247). Without market intervention, the investment into knowledge-based innovation may be unjustifiable because the risk is great that a competitor will appropriate the invention with modest, less risky investment.

With the patent right, government confers to an inventor the exclusive right to make, manufacture, distribute, and license to distribute the invention. To receive a patent the invention must be new or novel or show an inventive step and must have utility in the marketplace, a decision made through a formal examination process. The concept of novelty is core to the economics of technology innovation and the patent system (SCOTCHMER; GREEN, 1990). The examiner searches the relevant prior art to determine what a person having ordinary skill in the art knows and then makes a decision regarding the claim. Decisions may be appealed when an applicant fails and competitors may challenge the validity of the patent in court if they think the patent was granted by the patent office in error. Patent administration is thereby guided by a body of court-made administrative law that defines what concepts such as being new, novel, and nonobvious actually mean in practice (MERGES, 1988; DUFFY, 2007).

However, to describe a patent as conferring a monopoly is naïve (KITCH, 1980). The patent right is limited in duration in general to 20 years and is further limited by definition of its scope. Scope concerns the actual breadth of the claim of the patent: "The scope of the claims of a patent determines the ability of competitors to produce substitutes without fear of infringement suits, and hence the real market power of the patent holder" (MERGES; NELSON, 1994, p. 1). With the policy goal of preventing patent systems from becoming anti-competitive and, hence, innovation-discouraging rather than innovation-encouraging, legislatures and courts have attempted through the years to balance the incentive of exclusivity against the incentive of competition when setting the proper scope, or breadth, of patent (MERGES; NELSON, 1990, p. 839). Institutional economists focus research on patent scope as critical to the economics of

RAI - Revista de Administração e Inovação, São Paulo, v. 5, n. 3, p. 110-125, 2008. 
technology innovation entry and competition (KLEMPER, 1990; GILBERT; SHAPIRO, 1990; SCOTCHMER, 1991, 1996).

Since a patent confers exclusive rights in the marketplace over a product or process, albeit with time and scope limits, patent law demands full public disclosure of the know-how of the innovation when the patent is granted (ORDOVER, 1991). Patent documents thereby become useful sources of information regarding the economics of technology innovation. Study of patents counts can indicate research commitment, though actual innovativeness is a trickier issue (NARIN; NOMA; PERRY, 1987), and citation patterns can allow study of the trail of technology innovation across firms and countries and thereby reveal patterns (GRILICHES, 1990). Managerial economists thereby use patent data to study the social-organization and geography of R\&D and technology innovation (ALMEIDA; KOGUT, 1999).

The technology appropriability model also concerns the intellectual property notion of trade secrecy. A trade secret is information that can be specified with sufficient specificity, possesses commercial value, and that reasonable efforts have been taken to keep it secret. The law and policy of trade secrecy is rooted in notions of individual liberty, confidentiality, relational trust, common morality, and obligation as well as the notion of intellectual property (PAINE, 1991). Trade secret law and policy owes to incentives provided in market economies to holding valuable information dear and draws from the law of tort, contract, and competition and relates to patent law (KITCH, 1980). The inventor who decides to protect an innovation through trade secrecy simply does not disclose the know-how associated with the invention and does so for the competitive advantages conferred by exclusivity, information opaqueness, and potentially unlimited duration. However, trade secrets can be legally safeguarded against misappropriation but not against independent discovery or accidental leakage (FRIEDMAN; LANDES; POSNER, 1991). Thus, innovators sometimes determine that the limitations of trade secret protection make application for patent the better intellectual property management choice.

Technology innovators make their investment and business strategy decisions within particular intellectual property environments, what may be called the technology appropriability regime (TEECE, 1987). The technology appropriability regime ranges from tight or strong to loose or weak owing to how the laws are written by legislatures, implemented and administered by public administrators, and adjudicated by judges. Whether a technology appropriability regime is tight or loose has big implications for firm managers decide to manage their intellectual capital: "[Intangible] assets can be the source of competitive advantage only if they are supported by a regime of strong appropriability or are non-tradeable or 'sticky" " (that is, difficult by their nature to imitate, explains managerial economist TEECE, 2000, p. 20). That is, managers enter industry sector markets and country markets where they can appropriate superior returns on their technology and knowledge-based investments and avoid market entry where the risks of intellectual property leakage are unacceptably high.

Economic research regarding technology innovation shows that the researchbased pharmaceutical sector is the most patent-dependent of any industry sector (MANSFIELD, 1986; PAKES; SIMPSON, 1989). Innovative drugs are especially susceptible to the appropriability problem in knowledge-based economic activity, for turning a prospective chemical compound as identified in the laboratory into a drug that

RAI - Revista de Administração e Inovação, São Paulo, v. 5, n. 3, p. 110-125, 2008. 
may be distributed in the public health system requires many years of computer modeling, animal-testing and, finally, clinical trial testing. Clinical trials are performed in three phases and each phase results in a plethora of data. In Phase I, healthy volunteers are tested for dosage safety. In Phase II, a larger number of actual patients suffering from the malady are treated with the therapy to test for safety. In Phase III, many thousands of patients involving many hospitals and clinics are evaluated to demonstrate safety and efficacy.

Throughout this process, innovators will keep careful records of test results for quantitative and qualitative analysis. In theory the resulting research data could be kept a trade secret without term limit. In practice, however, government regulators obligate pharmaceutical innovators to provide the research data to them in order to determine whether the product achieves safety and efficacy standards and thus should be granted marketing approval. Governments require that regulators protect the research data from unfair commercial use by competitors and other third parties. The term of exclusivity under U.S. law is 5 years and up to 10 years in European practice from the registration date. After the data protection term expires, competing generic producers need not repeat the tests but need only show that their product is equivalent to the original chemical.

Economists compute the direct costs of the development process to about $\$ 300$ million for the typical new drug and, when the costs of capital and of failed R\&D efforts are included in the analysis, total $R \& D$ costs amount to about $\$ 800$ million (DIMASI; HANSEN; GRABOWKSI, 2003). Yet, the resulting compound - once known to be safe and effective - is easily reverse engineered and the actual manufacturing production costs are modest as a percentage of the innovation costs (DIMASI, 1995b).

Since only about one percent of chemical compounds identified as having therapeutic potential emerge from the development and regulatory process (DIMASI, 1995a), R\&D losers are a non-trivial issue that makes the drug innovation business exceedingly risky (GRABOWSKI; VERNON, 1990). However, just like prospectors staking real property claims when looking for gold, innovators stake their intellectual property claims with no guarantee that gold will be indeed their reward (KITCH, 1977). The economics of technological innovation are a lot like gambling or a lottery because most innovations are of modest value or even worthless (Scherer, 2000) and that economic reality has some big implications for innovators and policy-makers (SCHERER; HARHOFF, 2000). The gambling simile characterizes the blockbuster or bust nature of the innovative pharmaceutical business especially well. Managerial economists explain that innovative pharmaceutical companies keep growing through mergers and acquisitions as well as organically to create R\&D scope so that they can manage organizational learning opportunities, the huge financial capital demands, and the risks of product development failure (HENDERSON; COCKBURN, 1994, 1996).

The European experience with patents for the life sciences has been shaped by its political economy: diverse legal and policy responses from country-to-country, but a harmonization trend in law and administration owing to the European Patent Convention and establishment of the European Patent Office (though national patent offices continue to exist), but frequent and persistent social-political opposition to biomedical innovation progress and legal reform (STRAUS, 2003). Scherer and Weisburst (1995) addressed the question by studying the effect of patent reform in early-1980s Italy on pharmaceutical $\mathrm{R} \& \mathrm{D}$ and innovation. They found that the effect had been modest, but cautioned that the

RAI - Revista de Administração e Inovação, São Paulo, v. 5, n. 3, p. 110-125, 2008. 
Italian government had enforced the most stringent pharmaceutical price controls in Europe during their reform era, which may have "overwhelmed the stimulative incentive effects of drug product patent protection" (SCHERER; WEISBURST, 1995, p. 1023).

Japanese patent reforms of 1988 intended to encourage more technology innovation, but did not have much impact across technologies in the 1990s, perhaps because the corporate sector remained on its path-dependencies and the overall environment did not encourage entrepreneurship (SAKAKIBARA; BRANSTETTER, 2001). But, the pharmaceutical sector in Japan did increase its innovative activity (KAWAURA; LACROIX, 1995). Effective patent rights do not by themselves foment technology innovation.

\section{BIO-MEDICAL "MARKETS FOR TECHNOLOGY"}

Successful technology commercialization entails product/service development, production, and distribution. However, the technological innovator need not possess all these capabilities--or, complementary assets-within the organization. Some of the essential questions of technology management concern which capabilities to possess, acquire, or build inside the organization and which capabilities to leave to a partner. When these capabilities can be gained through partnership, then efficient technology markets play vital facilitating roles (ARORA; FOSFURI; GAMBARDELLA, 2001). From a managerial perspective, technology leakage should be minimized; technology transactions should be as efficient as possible. Sufficiently strong appropriability regimes establish the institutional conditions for markets for technology (ARORA, 1997).

That is, sufficiently strong appropriability regimes facilitate licensing and crosslicensing relationships between and among business partnerships. The parties to a licensing or cross-licensing of technology relationship look to patent rights so that the nature of the knowledge to be transferred and the terms of its use can be specified through contract (GRINDLEY; TEECE, 1997). By contrast, without efficient technology markets technology innovators have either to possess, acquire, or build the complementary assets themselves - or fail in the marketplace with the new technology.

Universities in the United States have become important participants in technology markets. The traditional means used by universities to disseminate their knowledge has included the hosting of research seminars on their campuses to discuss works-in-progress; presentations at scholarly research conferences attended by specialists in particular disciplines and fields; publication in peer-reviewed scholarly research journals; and helping their students find jobs in academic, government, and industry research settings. American policymakers came to believe in the late 1970s that this generally effective research system was nevertheless not as effective as it could be at encouraging the commercialization of research findings with potential market applications: Too many promising technologies remained shelved rather than commercialized.

The United States Congress with the Bayh-Dole Act and the Cooperative Research and Development Act (CRADA) gave universities and government research laboratories the authority to apply for patents for research findings that resulted from public funding so that rights to the research could be formally licensed to the private sector for further development and commercialization. The policy rationale was that

RAI - Revista de Administração e Inovação, São Paulo, v. 5, n. 3, p. 110-125, 2008. 
property rights would provide incentives to individual university researchers to consider market applications in their research, to the administrators at universities to organize for technology transfer, and to private industry to invest in further commercial development of basic technologies.

These policy reforms were controversial at the time and have become perhaps more controversial as the number of patents earned by universities has increased. The primary effect of Bayh-Dole on university research has been the establishment of technology transfer offices (TTOs) at many research universities, a substantial increase in the number of patents earned by universities and their researchers, and a few examples of universities with substantial royalty revenues. To critics of Bayh-Dole, however, the primary effect has been mission conflict: Is the mission of the university to create and disseminate knowledge and, if so, why establish barriers to access? (SAMPAT, 2006). "[I] $\mathrm{f}$ the findings of publicly-funded university research are placed in the public domain, or are inexpensively licensed to anyone who wants to use them, competition alone may stimulate their widespread application" says one critic (MOWERY et al., 1999, p. 268). The claim that open dissemination of science and technology best facilitates technological progress, that patents and TTOs divert university resources away from the primary mission of basic research and public dissemination, is sobering and worthy of carefully scrutiny and study.

The Bayh-Dole critics inspired other social scientists to gather evidence and assess he merits of the critique. The following are some key research findings:

- Study of MIT's TTO, an operation that long pre-dates the Bayh-Dole Act, shows, even at a university famous for the number of patents earned, the number of technologies that get to the marketplace, and the number of students and faculty who start-up enterprises, patenting still represents a very small percentage of research activity at the university (AGRAWAL; HENDERSON, 2002).

- Most patents do not contribute much if any royalty revenues; only a few patents bring home substantial royalties and only one or two patents prove to be blockbusters (FELDMAN et al., 2002).

- An industry survey with the assistance of the Association of University Technology Managers finds that $85 \%$ of university research still needs more development research to be useful; $45 \%$ of university research needs a great deal more development research to be useful (THURSBY; THURSBY, 2002).

The economics of university patenting, hence, look like the economics of technology innovation more generally-i.e., most innovations fail in the marketplace. These economics of university patenting challenge TTOs to manage skillfully their resources, which tend to be modest: Many technologies do not merit the expense of the patent process; those that do depend on TTOs that identify the appropriate licensee(s) and that's a tricky proposition (MOWERY; SAMPAT; ZIEDONIS, 2002).

A managerial economist who studies technology innovation and markets asks perhaps the most critical question of all regarding the utility of Bayh-Dole: Do university patents lead to more commercialization successes? (SHANE, 2002). His evidence is about 1400 patents earned at MIT between 1980 and 1996, supplemented by interviews with the MIT TTO staff. He studied the licensees and the licenses that were later

RAI - Revista de Administração e Inovação, São Paulo, v. 5, n. 3, p. 110-125, 2008. 
terminated because the licensees "cannot make the technology work in a cost-effective manner, because their strategic plans change, because the company does not want to continue to pay license fees, or because they have changed the product or business that they are developing so that the intellectual property is no longer useful" (SHANE, 2002, p. 127).

Professor Shane finds that inventions are more likely to be licensed when patents are an effective mechanism for appropriating the returns to innovation because the patent system reduces the transaction costs of technology transfer. Effective university patents allow "commercialization to be undertaken by economic actors who possess a comparative advantage in that activity" (SHANE, 2002, p. 133). When the patents are ineffective, the technology is either developed by the inventor himself, often unsuccessfully, or goes undeveloped. He explains: "Technology commercialization involves a set of skills-including identifying customer needs, developing product concepts, designing products and processes, prototyping, and manufacturing - that university inventors rarely possess" (SHANE, 2002, p. 123). These findings comply with technology management principles and provide important support for the policy rationales provided by proponents of Bayh-Dole.

Study of contemporary industrial $R \& D$ finds that stronger patent rights matter more to smaller enterprises than to bigger enterprises, a finding the authors describe as "sensible, even obvious" but unexplored empirically (ARORA; CECCAGNOLI; COHEN, 2007, p. 392). Economic historians find that nineteenth century U.S. technology innovation was characterized by the presence of technology markets involving lone inventors who licensed their patents to enterprises that would then manufacture it or integrate it into their systems (LAMOREAUX; SOKOLOFF, 1999). There is some evidence, then, that if it is true that "the most successful economies are those that have a mix of innovative entrepreneurs and larger, more established firms... that refine and mass produce the innovations that entrepreneurs [...] bring to market" (BAUMOL; LITAN; SCHRAMM, 2007, p. 4), then patent rights may be especially important for the efficient technology markets that enable entrepreneurship, especially as pharmaceutical R\&D strategy has shifted toward rational design (NIGHTINGALE; MAHDI, 2006).

\section{$4 \quad$ A PATENT ANTI-COMMONS IN THE LIFE SCIENCES?}

There is also a school of thought that says that, while the logic of patents as incentives, is basically sound, the present global — and especially U.S. - patent system has established a bio-medical anti-commons with too many patents in general and excessively broad patents with respect to research tools in particular (HELLER; EISENBERG, 1998). Patent litigation, actual and the threat of it, influences technology management decisions. For example, empirical research shows that biotech firms with high litigation costs avoid additional patenting in research areas crowded with patents (LERNER, 1995). How judges behave regarding injunctive relief can have big impact on technology innovation strategies of firms (AYRES; KLEMPERER, 1999). Jaffe and Lerner (2004) contend that the anti-commons phenomenon is an emerging problem in the world economy and with Scott Stern are editing an annual series of research papers regarding Innovation Policy and the Economy under the auspices of the National Bureau of Economic Research.

RAI - Revista de Administração e Inovação, São Paulo, v. 5, n. 3, p. 110-125, 2008. 
The controversy has led to organized efforts to bring groups of scholars together to study these issues, such as the edited volumes led by New York University Law School (DREYFUSS; ZIMMERMAN; FIRST, 2001) and the American Enterprise Institute-Brookings Institution Joint Center for Regulatory Studies (HAHN, 2005). These two volumes shed a great deal of analytical light and summarize a great deal of scholarly research and debate, especially with respect to biotechnology (and software) patents and competition. Authors tend to divide between scholars concerned about patent thickets and litigation costs and associated chilling of technology innovation and scholars who focus on licensing, cross-licensing, patent pools, and markets for technology innovation as solutions to these problems. This scholarship, however, tends to be analytical rather than empirical. A Duke University Engineering School-Kauffman Foundation study sought to measure US-based global IP creation by study of the Patent Cooperation statistics of the World Intellectual Property Organization (WADHAWA et al., 2007). The researchers found the US share of world patenting rising, the distribution of patenting activity in the United States clustering in particular states, and US university and firm patent filings relatively concentrated among innovation leaders. The research, however, was not designed to apply the empirical findings to the controversies within institutional economics, so it remains unclear whether the numbers add up to a good or bad story for technology innovation in America.

The anti-commons thesis, if demonstrated empirically, would radically alter the law and economics of intellectual property. However, Heller and Eisenberg (1998) did not offer an empirical study or any real examples of the phenomena they imagine. Subsequent empirical study of pharmaceutical R\&D competition contends that patent blockages are typically overcome in the real-world marketplace through licensing, crosslicensing, and patent pools in contradiction to the anti-commons thesis (WALSH, 2003). Epstein and Kuhlik (2004) dismiss the Heller and Eisenberg thesis as inconsistent with both economic theory and marketplace experience. Cohen and Walsh (2007) report their recent empirical study findings that bio-medical R\&D projects stop $62 \%$ of the time because of lack of funding, $60 \%$ of the time because of lack of time, $29 \%$ of the time because of competition concerns, and $1 \%$ of the time because of patent concerns. Thus, there is a good deal of accumulating empirical research contradicting in the real world the thesis proposed in academic world that a patent anti-commons plagues life sciences R\&D.

In response to the public debates that have proliferated in recent years surrounding intellectual property and health, the World Health Organization established a special commission composed of leaders from public health, economics, and politics. The commission concluded in its 2006 report that intellectual property rights play a decisively important role in encouraging bio-medical innovation and cast doubt about the feasibility of non-IPR-based models proposed by some advocacy groups.

\section{REFERENCES}

AGRAWAL, Ajay; HENDERSON, Rebecca. Putting patents in context: exploring knowledge transfer from MIT. Management Science, Providence, v. 48, n. 1, p. 44-61, Jan. 2002.

RAI - Revista de Administração e Inovação, São Paulo, v. 5, n. 3, p. 110-125, 2008. 
ARTICLES - How intellectual property rights encourage phamaceutical

ALMEIDA, Paul; KOGUT. Bruce. Localization of knowledge and the mobility of engineers in regional networks. Management Science, Providence, v. 45, n. 7, p. $905-$ 917, Jul. 1999.

ARORA, Ashish. Patent, licensing, and market structure in the chemical industry. Research Policy, Amsterdam, v. 26, n. 4/5, p. 392-403, Dec. 1997.

ARORA, Ashish; CECCAGNOLI, Marco; COHEN, Wesley M. Trading knowledge: an exploration of patent protection and other determinants of market transactions in technology and R\&D. In: LAMOREAUX, N. R.; SOKOLOFF, K. L. (Eds.). Financing innovation in the United States, 1870 to the present. Cambridge: MIT Press, 2007. p. $365-404$

ARORA, Ashish; FOSFURI, Andrea; GAMBARDELLA, Alfonso. Markets for technology: the economics of innovation and corporate strategy. Cambridge: MIT Press, 2001.

AYRES, Ian; KLEMPERER, Paul. Limiting patentees: market power without reducing innovation incentives: the perverse benefits of uncertainty and non-injunctive remedies. Michigan Law Review, v. 97, n. 4, p. 985-1033, Feb. 1999.

BAUMOL, William J. The free market innovation machine. Princeton: Princeton University Press, 2003.

BAUMOL, William J.; LITAN, Robert E.; SCHRAMM, Carl J. Good capitalism, bad capitalism, and the economics of growth and prosperity. New Haven: Yale University Press, 2007.

BRANSCOMB, Lewis M. Empowering technology: implementing a U.S. Strategy. Cambridge: MIT Press, 1995.

COHEN, Wesley M.; WALSH, John P. Real impediments to academic biomedical research. In: JAFFE, Adam P.; LERNER, Josh; STERN, Scott (Eds.). Innovation policy and the economy. Chicago: University of Chicago Press, 2007. v.8, p. 1-31.

DAM, Kenneth. The economic underpinnings of patent law. Journal of Legal Studies, Chicago, v. 23, n. 1, p. 247-271, Jan. 1994.

DAVID, Paul A. Innovation and Europe's academic institutions - second thoughts about embracing the Bayh-Dole regime. In: MALERBA, Franco; BRUSONI, Stefano (Eds.). Perspectives on innovation. New York: Cambridge University Press, 2007. p. 251-278.

DIMASI, Joseph A. Success rates for new drugs entering clinical testing in the United States. Clinical Pharmacology and Therapeutics, St. Louis, v. 58, p. 1-14, Feb. 1995a.

DIMASI, Joseph A. Trends in drug development costs, times, and risks. Drug Information Journal, Washington, v. 29, p. 375-384, 1995 b.

RAI - Revista de Administração e Inovação, São Paulo, v. 5, n. 3, p. 110-125, 2008. 
DIMASI, Joseph A.; HANSEN, Ronald W.; GRABOWSKI, Henry G. The price of innovation: new estimates of drug development costs. Journal of Health Economics, Amsterdam, v. 22, n. 2, p. 151-185, Mar. 2003.

DREYFUSS, Rochelle; ZIMMERMAN, Diane L.; FIRST, Harry (Eds.). Expanding the boundaries of intellectual property: innovation policy for the knowledge society. New York: Oxford University Press, 2001.

DUFFY, John F. Inventing invention: a case study of legal innovation. Texas Law Review, Austin, v. 86, n. 1, p. 1-72, Nov. 2007.

EISENBERG, Rebecca S. Patents and the progress of science: exclusive rights and experimental use. University of Chicago Law Review, Chicago, v. 56, p. 1017-1086, 1989. .

EISENBERG, Rebecca S. Proprietary rights and the norms of science in biotechnology research. Yale Law Journal, New Haven, v. 97, n. 2, p. 179-231, Dec. 1987.

EISENBERG, Rebecca S. Public Research and private development: patents and technology transfer in government-sponsored research. Virginia Law Review, Charlottesville, v. 83, p. 1663-1727, 1996. .

EPSTEIN, Richard A.; KUHLIK, Bruce N. Is there a biomedical anticommons? Regulation, Washington, v. 27, n. 2, p. 54-58, 2004.

FELDMAN, Maryann et al. Equity and the technology transfer strategies of american research universities. Management Science, Providence, v. 48, n. 1, p. 105-121, Jan. 2002.

FRIEDMAN, David D.; LANDES, William M.; POSNER, Richard A. Some economics of trade secret law. Journal of Economic Perspectives, Nashville, v. 5, n. 1, p. 61-72, 1991.

GALAMBOS, Louis; SEWELL, Jane Eliot. Networks of innovation: vaccine development at Merck, Sharp and Dohme \& Mulford, 1895-1995. New York: Cambridge University Press, 1995.

GILBERT, Richard; SHAPIRO, Carl. Optimal patent protection and breadth. Rand Journal of Economics, Mount Morris, v. 21, n. 1, p. 106-112, 1990.

GRABOWSKI, Henry G.; VERNON, John. A new look at the returns and risks to pharmaceutical R\&D. Management Science, Providence, v. 6, n. 7, p. 804-821, Jul. 1990.

GRILICHES, Zvi. Patent statistics as economic indicators: a survey. Journal of Economic Literature, Nashville, v. 28, n. 4, p. 1661-1707, Dec. 1990.

GRINDLEY, Peter C.; TEECE, David J. Managing intellectual capital: licensing and cross-licensing in semiconductors and electronics. California Management Review, Berkerly, v. 39, n. 2, p. 8-41, 1997.

RAI - Revista de Administração e Inovação, São Paulo, v. 5, n. 3, p. 110-125, 2008. 
ARTICLES - How intellectual property rights encourage phamaceutical

HAHN, Robert W. (Ed.). Intellectual property rights in frontier industries: software and biotechnology. Washington, DC: American Enterprise Institute, 2005.

HELLER, Michael A.; EISENBERG, Rebecca S. Can patents deter innovation? The anticommons in biomedical research. Science, Washington, v. 280, n. 5364, p. 698-701, May 1998.

HENDERSON, Rebecca; COCKBURN, Iain. Measuring competence? Exploring firm effects in pharmaceutical research. Strategic Management Journal, Chichester, v. 15, p. 63-84, Winter 1994.

HENDERSON, Rebecca; COCKBURN, Iain. Scale, scope, and spillovers: the determinants of research productivity in drug discovery. RAND Journal of Economics, Mount Morris, v. 27, n. 1, p. 32-59, 1996.

JAFFE, Adam B.; LERNER, Josh. Innovation and its discontents: how our broken patent system in endangering innovation and progress and what to do about it. Princeton: Princeton University Press, 2004.

KAWAURA, Akhiko; LACROIX, Summer J. Japan's shift from process to product patents in the pharmaceutical industry: an event study of the impact on Japanese firms.

Economic Inquiry, Huntington Beach, v. 33, n. 1, p. 88-103, Jan. 1995.

KITCH, Edmund W. The law and economics of rights in valuable information. Journal of Legal Studies, Chicago, v. 9, n. 4, p. 683-723, Dec. 1980.

KITCH, Edmund W. The nature and function of the patent system. Journal of Law and Economics, Chicago, v. 20, n. 2, p. 265-290, Oct. 1977.

KLEMPERER, Paul. How broad should the scope of patent protection be? RAND Journal of Economics, Mount Morris, v. 21, n. 1, p. 113-130, 1990.

KUEHN, Thomas J.; PORTER, Alan L. Science, technology, and national policy. Washington, DC: Brookings Institution Press, 1981.

LAMOREAUX, Naomi R.; SOKOLOFF, Kenneth. Inventors, firms, and markets in the late nineteenth century/early twentieth centuries. In: LAMOREAUX, Naomi R.; RAFF, Daniel M. G.; TEMIN, Peter (Eds.). Learning by doing in markets, firms, and countries, Chicago: University of Chicago Press, 1999. p. 19-60.

LERNER, Josh. Patenting in the shadow of competitors. Journal of Law and Economics, Chicago, v. 38, n. 2, p. 463-495, Oct. 1995.

MANSFIELD, Edwin. Patents and innovation: an empirical study. Management Science, Providence, v. 32, n. 2, p. 173-181, Feb. 1986.

MERGES, Robert P. Ccommercial success and patent standards: economic perspectives on innovation. California Law Review, Berkerley, v. 76, n. 4, p. 805-876, 1988.

MERGES, Robert P. A transactional view of property rights. Berkeley Technology Law Journal, Berkerly, v. 20, n. 4, p. 1477-1520, 2005.

RAI - Revista de Administração e Inovação, São Paulo, v. 5, n. 3, p. 110-125, 2008. 
MERGES, Robert P. Of property rules, coase, and intellectual property. Columbia Law Review, New York, v. 94, p. 2664-2655, 1994.

MERGES, Robert P.; NELSON, Richard R. On limiting or encouraging rivalry in technical progress: the effect of patent-scope decisions. Journal of Economic Behavior and Organization, Amsterdam, v. 25, n. 1, p. 1-24, Sept. 1994.

MERGES, Robert P.; NELSON, Richard R. On the complex economics of patent scope. Columbia Law Review, New York, v. 90, n. 4, p. 839-916, May 1990.

MOWERY, David C. University-industry collaboration and technology transfer in the United States Since 1980. In: YUSUF, Shahid; NABESHIMA, Kaoru (Eds.). How universities promote economic growth. Washington, DC: The World Bank, 2007. p. $163-182$.

MOWERY, David C. et al. The effects of Bayh-Dole Act on U.S. university research and technology transfer. In: BRANSCOMB, Lewis M.; KODAM, Fumio; FLORIDA, Richard (Eds.). Industrializing knowledge: university-industry linkages in Japan and the United States. Cambridge: MIT Press, 1999. p. 269-306.

MOWERY, David C.; SAMPAT, Bhaven N.; ZIEDONIS. Arvid A. Learning to patent: institutional experience, learning, and the characteristics of U.S. university patents after the Bayh-Dole Act, 1981-1992. Management Science, Providence, v. 48, n. 1, p. 73-89, 2002.

NARIN, Francis; NOMA, Elliot; PERRY, Rossy. Patents as indicators of corporate technological strength. Research Policy, Amsterdam, v. 16, n. 2/4, p. 143-155, Aug. 1987.

NELSON, Richard R. (Ed.). National innovation systems: a comparative analysis. New York: Oxford University Press, 1993.

NELSON, Richard R. The market economy and the scientific commons. Research Policy, Amsterdam, v. 33, n. 3, p. 455-471, Apr. 2004.

NIGHTINGALE, Paul; MAHDI, Surya Mahdi. The evolution of pharmaceutical innovation. In: MAZZUCATO, Mariana; DOSI, Giovanni (Eds.). Knowledge accumulation and industry evolution. New York: Cambridge University Press, 2006. p. $73-111$.

NORTH, Douglass C. Structure and change in economic history. New York: Norton, 1981.

ORDOVER, Janus A. A patent system for both diffusion and exclusion. Journal of Economic Perspectives, Nashville, v. 5, n. 1, p. 43-60, 1991.

OWEN-SMITH, Jason et al. A comparison of U.S. and European university-industry relations in the life sciences. Management Science, Providence, v. 48, n. 1, p. 24-43, Jan. 2002.

RAI - Revista de Administração e Inovação, São Paulo, v. 5, n. 3, p. 110-125, 2008. 
ARTICLES - How intellectual property rights encourage phamaceutical

PAINE, Lynn Sharpe. Trade secrets and the justification of intellectual property. Philosophy and Public Affairs, Princeton, v. 20, n. 3, p. 247-263, 1991.

PAKES, Ariel; SIMPSON, Margaret Simpson. Patent renewal data. In: WINSTON, Clifford; BAILY, Martin Neil (Eds.). Brookings papers on economic activity, microeconomics. Washington, DC: Brookings Institution, 1989. p. 331-401.

RAI, Arti K. Evolving scientific norms and intellectual property rights: a reply to Kieff. Northwestern University Law Review, Chicago, v. 95, p. 704-714, 2001.

RAI, Arti K. Regulating scientific research: intellectual property rights and the norms of science. Northwestern University Law Review, Chicago, v. 94, n. 1, p. 77-152, 1999.

ROSENBERG, Nathan; LANDAU, Landau; MOWERY, David C. (Eds.). Technology and the wealth of nations. Stanford: Stanford University Press, 1992.

SAKAKIBARA, Mariko; BRANSTETTER, Lee G. Do Stronger patents induce more innovation? Evidence from the 1988 Japanese patent reforms. RAND Journal of Economics, Mount Morris, v. 32, n. 1, p. 77-100, 2001.

SAMPAT, Bhaven N. Patenting and U.S. academic research in the twentieth century: the world before and after Bayh-Dole. Research Policy, Amsterdam, v. 35, n. 6, p. 772-789, Jul. 2006.

SCHERER, Frederick M.; HARHOFF, Dietmar; KUKIES, Jörg. Uncertainty and the size distribution of rewards from technological innovation. Journal of Evolutionary

Economics, Dordrecht, v. 10, n. 1/2, p. 175-181, 2000.

SCHERER, Frederick M.; HARHOFF, Dietmar. Technology policy for world of skewdistributed outcomes. Research Policy, Amsterdam, v. 29, n. 4/5, p. 559-566, Apr. 2000.

SCHERER, Frederick M.; WEISBURST, Sandy. economic effects of strengthening pharmaceutical patent protection in Italy. International Review of Industrial Property and Copyright Law, Munich, v. 26, p. 1009-1024, 1995.

SCOTCHMER, Suzanne. Protecting early innovators: should second-generation products be patentable? RAND Journal of Economics, Mount Morris, v. 27, n. 2, p. 322-331, 1996.

SCOTCHMER, Suzanne. Standing on the shoulders of giants: cumulative research and the patent law. Journal of Economic Perspectives, Nashville, v. 5, n. 1, p. 29-41, 1991.

SCOTCHMER, Suzanne; GREEN, Jerry. Novelty and disclosure in patent law. RAND Journal of Economics, Mount Morris, v. 21, n. 1, p. 131-146, 1990.

SCRIABINE, Alexander. Discovery and development of major drugs currently in use. In: LANDAU, Ralph; ACHILLADELIS, Basil; SCRIABINE, Alexander (Eds.).

Pharmaceutical innovation. Philadelphia: Chemical Heritage Foundation, 1999. p. 148270.

RAI - Revista de Administração e Inovação, São Paulo, v. 5, n. 3, p. 110-125, 2008. 
SHANE, Scott. Selling university technology: patterns from MIT. Management Science, Providence, v. 48, n. 1, p. 122-137, Jan. 2002.

SOETE, Luc. Notes on UIL-related policies of national governments. In: YUSUF, Shahid; NABESHIMA, Karoru (Eds.). How universities promote economic growth. Washington, DC: The World Bank, 2007. p. 29-46.

STEIL, Ben; VICTOR, David G.; NELSON, Richard R. (Eds.). Technological innovation and economic performance. Princeton: Princeton University Press, 2002.

STRAUSS, Joseph. Patenting of life forms: the European experience and perspectives. In: COTTIER, Thomas; MAVROIDIS, Petros C. (Eds.). Intellectual property: trade, competition, and sustainable development. Michigan: University of Michigan Press, 2003. p. 341-358.

TEECE, David J. Managing intellectual capital. New York: Oxford University Press, 2000.

TEECE, David J. Profiting from technological innovation: implications for integration, collaboration, licensing, and public policy. Research Policy, Amsterdam, v. 15, n. 6, p. 285-305, Dec. 1987.

THURSBY, Jerry G.; THURSBY, Marie C. Who is selling the ivory tower? Sources of growth in university licensing. Management Science, Providence, v. 48, n. 1, p. 90-104, Jan. 2002.

WADHAWA, Vivek et al. U.S-based global intellectual property creation: an analysis. Kansas City: Kauffman Foundation, 2007.

WALSH, John P. Working through the patent problem. Science, New York, v. 299, n. 5609, p. 1021, 2003.

ZIEGLER, J. Nicholas. Institutions, elites, and technological change in France and Germany. World Politics, Princeton, v. 47, n. 2, p. 341-372, Apr. 1995.

\section{COMO OS DIREITOS DE PROPRIEDADE INTELECTUAL INCENTIVAN A INOVAÇÃO NA INDÚSTRIA FARMACÊUTICA}

\section{Resumo}

Por meio de patentes, governos intervêm nos mercados para prover incentivos aos agentes inovadores para investir o seu conhecimento, tempo e dinheiro na criação de invenções no contexto do problema da apropriação associada a ativos intangíveis. A noção de propriedade intelectual enquanto segredo de transação significa um conjunto de informação específica que contém valor comercial e que algum sacrifício foi feito para torná-lo e mantê-lo secreto. Produtos farmacêuticos inovadores, de caráter radical ou incremental, são especialmente suscetíveis ao problema da apropriação nas atividades econômicas baseadas em conhecimento. Tornar uma molécula identificada em

RAI - Revista de Administração e Inovação, São Paulo, v. 5, n. 3, p. 110-125, 2008. 
ARTICLES - How intellectual property rights encourage phamaceutical

laboratório em um fármaco que poderá ser distribuído pelo sistema de saúde pública demanda muitos anos de modelagem de computador, testes em animais e, finalmente, testes clínicos em humanos. Testes clínicos são desenvolvidos em três fases e cada um redunda em uma pletora de dados. Nos Estados Unidos, as leis de vigilância sanitária especificam que estes dados sejam mantidos confidenciais e disponíveis para as autoridades reguladoras por um período de cinco anos. Na Europa o período é ainda maior. Regimes de apropriação suficientemente fortes facilitam a licença e a intra-licença entre universidades e empresas de negócios. Suficiente evidência empírica apóia a utilização do modelo Bayh-Dole e coloca sérias dúvidas sobre a existência do sistema de patentes anti-commons (nota do editor: quando a existência de muitos proprietários frustra um resultado socialmente desejável), nas ciências da vida.

Palavras-chave: Anti-commons, drogas inovadoras, indústria farmacêutica, patentes.

Data do recebimento do artigo: 20/10/2008

Data do aceite de publicação: 15/12/2008

RAI - Revista de Administração e Inovação, São Paulo, v. 5, n. 3, p. 110-125, 2008. 